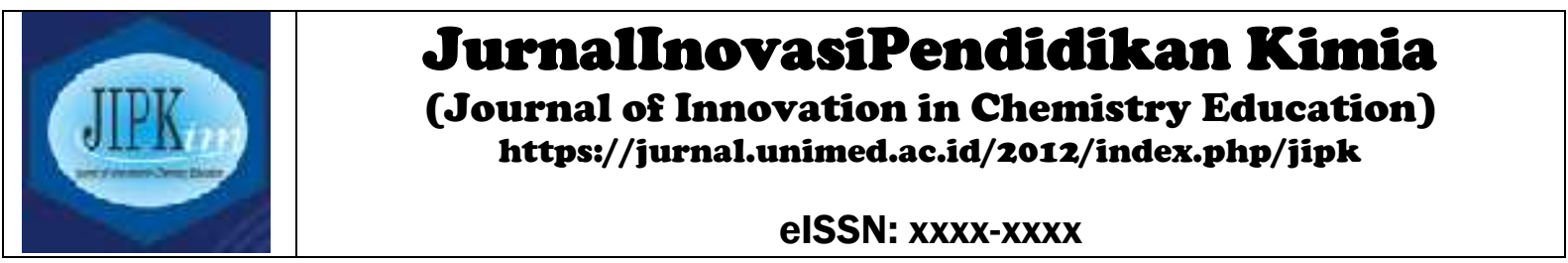

\title{
Perbedaan Hasil Belajar Kimia Siswa Berbantuan Peta Konsep dan Peta Pikiran Menggunakan CIRC
}

\author{
Hafni Indriati Nasution ${ }^{\mathrm{a}, *}$, Makharany Dalimunthe ${ }^{\mathrm{a}}$, Dian Yustika Rini Nasution ${ }^{\mathrm{a}}$ \\ ${ }^{a} J u r u s a n$ Pendidikan Kimia, Universitas Negeri Medan, Medan \\ *Alamat Korespondensi: hafniindriatinst@gmail.com
}

\begin{abstract}
:
This study aims to determine the differences in the chemistry learning outcomes of students taught with the help of media Concept Maps and Mind Maps using Cooperative Integrated Reading and Composition (CIRC) learning models on colloid subject matter. The population in this study is all students of class XI MIA SMA Swasta Nusantara Lubuk Pakam in the 2017/2018 school year consisting of 3 classes. The sample used in this study was taken by random sampling of two classes. The data analysis technique is a hypothesis test, namely the two-tail t-test. Based on the results of the data requirements test, it is known that the data from the pretest and posttest in the experimental class I and experiment II are normally distributed and homogeneous. Whereas to test the hypothesis on student learning outcomes (posttest) the price -thitung $<-t^{1} / 2 \alpha$ and tcount $<t 1 / 2 \alpha$ $(-2,2181<-2,002$ and 2,2181>2,002) and are in the critical area, then Ho is rejected Ha accepted is that there are differences in chemistry learning outcomes of students who are taught with the help of media Concept Maps and Mind Maps using Cooperative Integrated Reading and Composition (CIRC) learning models on the subject matter of colloids.
\end{abstract}

Keywords: Results Learning chemistry of students, circ, concept maps, mind maps, colloids

\section{PENDAHULUAN.}

Pendidikan merupakan suatu kebutuhan yang mendasar bagi kemajuan suatu bangsa. Salah satu masalah pendidikan yang dihadapi bangsa Indonesia adalah rendahnya mutu pendidikan bagi setiap jenjang dan satuan pendidikan. Untuk mencapai kemajuan harus ada upaya yang sungguh-sungguh baik dari lembaga resmi pemerintah atau masyarakat pada umumnya. Sekolah sebagai lembaga pendidikan formal yang mendapat prioritas utama untuk menyelenggarakan proses belajar mengajar, mempunyai tugas dan tanggung jawab yang besar. Oleh karena itu diperlukan suatu strategi belajar mengajar yang paling efektif dan efisien (Margianto, 2017).

Salah satu perubahan paradigma pembelajaran adalah orientasi pembelajaran yang semula berpusat pada guru (teacher centered) beralih berpusat pada murid (student centered), metodologi yang semula lebih didominasi ekspositori berganti ke partisipatori, dan pendekatan yang semula lebih banyak bersifat tekstual berubah menjadi kontekstual dimaksudkan untuk memperbaiki mutu pendidikan baik dari segi proses maupun hasil (Sukarini dkk., 2013).

Ilmu kimia merupakan ilmu yang sangat penting, namun pada kenyataannya kimia merupakan salah satu mata pelajaran yang dianggap sulit bahkan dianggap beban oleh sebagian besar siswa. Materi yang dipelajari seolah-olah bersifat khayalan dan tak nyata karena tidak bisa dilihat langsung oleh kasat mata sehingga menyebabkan siswa kurang tertarik dalam mempelajarinya (Wardani \& Suharto, 2015). 
Koloid merupakan materi dalam pelajaran kimia yang ada di semester dua kelas XI. Materi Koloid terdiri atas dua Kompetensi Dasar (KD) yaitu sistem koloid dan pembuatan koloid. Kekhasan materi koloid adalah bersifat abstrak, sedangkan contohnya bersifat konkrit (Hanum dkk., 2014).

Berdasarkan hasil observasi peneliti dan wawancara dengan guru kimia di sekolah SMA Swasta NusantaraLubuk Pakam, diperoleh ratarata hasil belajar siswa yang rendah dan tidak memenuhi KKM. Sedangkan nilai KKM yang dimiliki sekolah tersebut adalah sebesar 75 , berarti siswa yang memiliki nilai minimal dibawah 75 belum dikatakan tuntas.

Banyak siswa menyatakan bahwa pelajaran kimia merupakan pelajaran yang sulit karena banyak konsep-konsep yang harus dihapalkan dan mengarahkan kepada kehidupan sehari-hari yang kurang dipahami oleh siswa. Hal ini juga disebabkan oleh pembelajaran yang masih menggunakan pembelajaran konvensional yang berpusat pada guru (teacher centered approach) sehingga membuat siswa tidak tertarik dan tidak adanya rasa ingin tahu ketika proses belajar berlangsung yang berdampak pada rendahnya hasil belajar siswa.

Untuk mengantisipasi masalah tersebut agar tidak berkelanjutan, maka guru berusaha menyusun dan menerapkan model pembelajaran (Margianto, 2017). Model pembelajaran yang dapat menunjang hasil belajar siswa adalah model pembelajaran kooperatif tipe Cooperative Integrated Reading and Composition (CIRC) (Hanum dkk., 2014). Pembelajaran kooperatif tipe Cooperative Integrated Reading and Composition (CIRC) dari segi bahasa dapat diartikan sebagai suatu model pembelajaran kooperatif yang mengintegrasikan suatu bacaan secara menyeluruh kemudian mengkomposisikannya menjadi bagian bagian yang penting (Sastika dkk., 2013).
Kelebihan metode CIRC ini adalah siswa dituntut untuk memahami materi dari berbagai bacaan yang ada (Sukarini dkk., 2013).

Menurut Istarani (2012) langkahlangkah terukur dan sistematis dari model pembelajaran ini sebagai berikut:

1. Membentuk kelompok yang anggota nya 4 orang secara heterogen.

2. Guru memberikan wacana/Kliping sesuai dengan topik pembelajaran.

3. Peserta didik bekerja sama saling membacakan dan menemukan ide pokok dan memberi tanggapan terhadap wacana/kliping dan ditulis dalam selembar kertas.

4. Mempresentasikan / membacakan hasil kelompok.

5. Guru membuat kesimpulan bersama.

6. Penutup.

Berdasarkan hasil penelitian yang dilakukan oleh Hanum dkk. (2014), disimpulkan bahwa penggunaan model pembelajaran kooperatif tipeCooperative Integrated Reading and Composition (CIRC) meningkatkan nilai rata-rata belajar siswa dari 6,20 menjadi 8,40.

Selain menerapkan model pembelajaran kooperatif sebagai upaya untuk meningkatkan hasil belajar siswa diperlukan juga sebuah media pembelajaran. Untuk melengkapi model pembelajaran CIRC dapat digunakan media pembelajaran berupa peta konsep dan peta pikiran.

Peta konsep merupakan media pendidikan yang dapat menunjukkan konsep ilmu yang sistematis, yaitu dimulai dari inti permasalahan sampai pada bagian pendukung yang mempunyai hubungan satu dengan lainnya, sehingga dapat membentuk pengetahuan dan mempermudah pemahaman suatu topik pelajaran (Jati dkk., 2015).

Menurut Jati dkk (2015) Kelebihan peta konsep adalah:

1. Dapat menunjukkan secara visual berbagai jalan yang dapat 
ditempuh dalam menghubungkan pengertian konsep di dalam permasalahanya.

2. Peta konsep yang dibuat murid dapat membantu guru untuk mengetahui miskonsepsi yang dimiliki siswa dan untuk memperkuat pemahaman konseptual guru sendiri dan disiplin ilmunya.

Peta pikiran adalah alat berpikir kreatif melibatkan setiap aspek dari otak kiri dan kanan, dan karenanya merupakan alat pikir istimewa yang melibatkan seluruh bagian otak. Peta pikiran memungkinkan otak menggunakan semua gambar dan asosiasinya dalam pola radial dan jaringan sebagaimana otak dirancang (Jati dkk., 2015).

Kelebihan peta pikiran adalah seperti yang diketahui bersama otak manusia itu terbagi menjadi dua yaitu otak kiri dan kanan. Otak yang digunakan dalam belajar biasanya selalu otak kiri. Hal ini yang menyebabkan terjadi ketidakseimbangan dalam belajar yang dilakukan menjadi tidak efektif. Peta pikiran akan menggunakan otak kanan, karena dalam prosesnya dengan membuat gambar, garis, warna, dan kata-kata. Dengan metode tersebut belajar akan lebih menyenangkan, materi belajar akan cepat diingat, ide-ide akan muncul, waktu akan lebih efektif, dan hasil belajar bisa memuaskan (Jati dkk., 2015).

Dari beberapa hasil penelitian yang menunjukkan bahwa model pembelajaran kooperatif tipe Cooperative Integrated Reading and Composition (CIRC) dan penggunaan media peta konsep dan peta pikiran memberikan perbedaan yang signifikan terhadap hasil belajar siswa. Dengan demikian, penelitian ini bertujuan untuk menggunakan model dan media pembelajaran tersebut yang dapat meningkatkan hasil belajar siswa dalam pelajaran kimia pada materi Koloid di SMA.

\section{METODE}

Penelitian ini menggunakan metode eksperimen. Metode ini akan dilakukan pada dua kelas yaitu kelas eksperimen I dan kelas eksperimen II. Rancangan penelitian ini menggunakan desain seperti tabel dibawah ini :

Tabel 1. Rancangan Penelitian

\begin{tabular}{llll}
\hline Kelompok & Pretest & Perlakuan & Posttest \\
\hline Eksp I & $\mathrm{X}_{1}$ & $\mathrm{~A}$ & $\mathrm{X}_{2}$ \\
\hline Eksp II & $\mathrm{X}_{1}$ & $\mathrm{~B}$ & $\mathrm{X}_{2}$ \\
\hline
\end{tabular}

Keterangan :

$\mathrm{X}_{1}=$ Hasil belajar pada awal penelitian (pre-test)

$\mathrm{X}_{2}=$ Hasil belajar pada akhir penelitian (post-test)

$\mathrm{A}=$ Perlakuan dengan model pembelajaran Cooperative Integrated Reading and Composition (CIRC)berbantuan media Peta Konsep.

$\mathrm{B}=$ Perlakuan dengan model pembelajaran Cooperative Integrated Reading and Composition (CIRC)berbantuan media Peta Pikiran.

Populasi dalam penelitian ini adalah seluruh siswa kelas XIMIA SMA Swasta Nusantara Lubuk Pakam Semester genap Tahun Ajaran 2017/2018 yang terdiri dari 3 kelas dengan jumlah siswa 90 orang dimana masing masing kelas terdiri dari 30 orang. kelas XI MIA 1 sebagai kelas eksperimen I dan kelas XI MIA 2 sebagai kelas eksperimen II diberikan pengajaran dengan media peta konsep dan peta pikiran menggunakan Model Pembelajaran Cooperative Integrated Reading and Composition (CIRC) pada Materi Koloid. Data yang didapatkan dalam penelitian ini diperoleh dari pretest yang diujikan sebelum dilakukan proses pembelajaran pada kedua kelompok sampel (kelas eksperimen I dan kelas eksperimen II) dan postest yang diujikan setelah dilakukan proses pembelajaran menggunakan model Cooperative Integrated Reading and Composition (CIRC) menggunakan media peta konsep pada kelas eksperimen I dan model Cooperative Integrated Reading 
and Composition (CIRC) menggunakan media peta pikiran pada kelas eksperimen II.

Variabel Bebas dalam penelitian ini adalah model pembelajaran Cooperative Integrated Reading and Composition (CIRC), media peta konsep,dan media peta pikiran. Dan yang menjadi variabel terikat dalam penelitian adalah hasil belajar kimia siswa yang berkaitan dengan materi Koloid. Sedangkan yang menjadi variabel kontrol dalam penelitian ini adalah guru, waktu, buku kimia kelas XI SMA/MA dan materi yang diajarkan adalah sama.

Instrumen pengambilan data yang meliputi Instrumen penilaian kognitifTeknik analisis Instrumen kognitif menggunakan: (1) Uji validitas, penentuan validitas tes menggunakan rumus korelasi Product Moment untuk validitas isidan instrumen dinyatakan valid (2) Uji reliabilitas, digunakan rumus Kuder Richardson (KR-20). Hasil uji coba reliabilitas, instrumen dinyatakan reliable sebab harga reliabilitas sebesar0,83lebih besar dari kriteria minimum (0,355), (3) Tingkat kesukaran, ditentukan atas banyaknya siswa yang menjawab benar butir soal dibanding jumlah seluruh siswa yang mengikuti tesSetelah dilakukan uji coba, dari 22 soal, 21 soal tergolong sedang, dan 1 soal tergolong sukar. (4) Daya pembeda suatu item, ditentukan dari proporsi test kelompok atas yang dapat menjawab dengan benar butir item yang bersangkutan dikurangi proporsi test kelompok bawah yang dapat menjawab dengan benar butir item tersebut. Setelah dilakukan ujicoba, dari 22 soal, 2 soal jelek, 11 soal cukup, dan 9 soal baik.

Teknik analisis data yang digunakan adalah uji t-pihak kanan yang mensyaratkan data normal dan homogen, untuk menguji apakah sampel penelitian dari populasi distribusi normal atau tidak digunakan metodeUji Chi Kuadratsedangkan untuk mengetahui apakah sampel penelitian mempunyai variansi yang homogen atau tidak digunakan metodeuji kesamaan varians.

\section{HASIL DAN PEMBAHASAN}

Data yang diperoleh dalam penelitian ini adalah prestasi belajar siswa pada materi pokok sistem koloid yang meliputi aspek kognitif. Data penelitian mengenai prestasi belajar secara ringkas disajikan pada Tabel 2 .

Tabel 2. Rangkuman Data Penelitian

\begin{tabular}{ccc}
\hline \multirow{2}{*}{ Jenis Penelitian } & \multicolumn{2}{c}{ Nilai Rata-Rata } \\
\cline { 2 - 3 } & Eksp I & Eksp II \\
\hline Postest Kognitif & 79,33 & 84,0 \\
\hline
\end{tabular}

$\begin{array}{ccr}\text { Berdasarkan Tabel } 2 & \text { terlihat } \\ \text { bahwa nilai kognitifpada } & \text { kelas }\end{array}$ eksperimen I (model pembelajaran CIRC disertai peta pikiran lebih tinggi dibandingkan kelas eksperimen II (model pembelajaran CIRC disertai peta konsep).

Uji normalitas dilakukan dengan metode Uji Chi Kuadrat pada taraf signifikansi sebesar 5\%. Hasil uji normalitas terangkum dalam Tabel 3 . Sedangkan uji homogenitas dilakukan dengan metode uji kesamaan varians pada taraf signifikansi 5\%. Ringkasan hasil uji homogenitas terangkum dalam Tabel 4. Berdasarkan Tabel 3 dan 4 data hasil penelitian dinyatakan terbukti normal dan homogen sebab harga $t_{\text {hitung }}<t_{\text {tabel }}$, sehingga data tersebut telah memenuhi syarat untuk uji t-pihak kanan.Hasil perhitungan uji t-pihak kanan dalam Tabel 5.

Tabel 3. Uji Normalitas

\begin{tabular}{|c|c|c|c|c|c|}
\hline Kelst: & Dats & $\tau^{2} \operatorname{san}$ & $\boldsymbol{F}_{3 \mathrm{~s}}^{2}$ & $\bar{A}$ & Kerelamgan \\
\hline R.hsportursn I & $\begin{array}{l}\text { setal } \\
\text { linstasi }\end{array}$ & $\begin{array}{l}\text { :105 } \\
\text { 4.. }\end{array}$ & $\mathrm{HL}, \mathrm{W}$ & ט.s & $\begin{array}{l}\text { Deiaturini } \\
\text { Nonisal }\end{array}$ \\
\hline $\begin{array}{l}\text { Lispietzenter } \\
\text { II }\end{array}$ & $\begin{array}{l}\text { aresel } \\
\text { linteral }\end{array}$ & $\begin{array}{l}x \\
y .1\end{array}$ & $11,: .7$ & 10.5 & $\begin{array}{l}\text { Detaktsoi } \\
\text { Nonyal }\end{array}$ \\
\hline Tabel 4. Uji & $\begin{array}{c}\text { Homog } \\
\text { Date }\end{array}$ & genitas & Frien:s,:s & $A$ & Ketmenngar \\
\hline 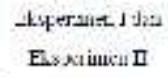 & $\begin{array}{l}\text { Fotest } \\
\text { Ruslisi: }\end{array}$ & $\begin{array}{l}\lfloor, 0049 \\
0.8631\end{array}$ & $1 \mathrm{ses}$ & asis & 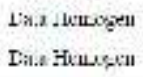 \\
\hline
\end{tabular}

Tabel 5. Uji Hipotesis 


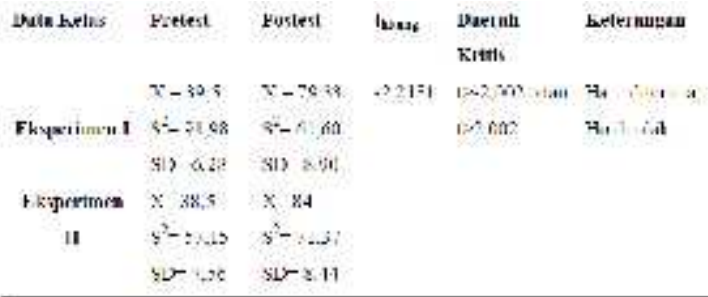

Berdasarkan data yang dituliskan di atas, hasil perhitungan uji t-pihak kanan pada Tabel 5 diperoleh thitung yang lebih besar daripada ttabel $=2,002$ dengan taraf signifikansi 5\%, maka Ho ditolak, dengan demikian nilai kognitif siswa kelas eksperimen I (penggunaan model pembelajaran CIRC disertai peta pikiran) lebih tinggi dari kelas eksperimen II (penggunaan model pembelajaran CIRC disertai peta konsep). Dengan ditolaknya Ho maka Ha diterima sehingga dapat diperoleh kesimpulan bahwa model pembelajaran CIRC disertai peta pikiran memberikan hasil prestasi belajar siswa lebih baik dibandingkan yang disertai peta konsep pada materi pokok sistem koloid.

Hasil dari penelitian ini didukung oleh penelitian sebelumnya yang telah yang dilakukan oleh Jati dkk (2015), disimpulkan bahwa penggunaan model pembelajaran CIRC (Cooperative Integrated Reading andComposition) dilengkapi peta pikiran memberikan prestasi belajar yang lebih baik dibandingkan yang dilengkapi peta konsep pada materi pokok Sistem Koloid.

Berdasarkan hasil penelitian yang dilakukan oleh Hanum dkk. (2014), disimpulkan bahwa penggunaan model pembelajaran kooperatif tipe Cooperative Integrated Reading and Composition (CIRC) meningkatkan nilai rata-rata belajar siswa dari 6,20 menjadi 8,40. Kemudian Berdasarkan penelitian yang dilakukan oleh Mardhiah dan Juwita (2016), model pembelajaran kooperatif tipe Cooperative Integrated Reading and Composition (CIRC) dapat meningkatkan hasil belajar kimia siswa diketahui melalui persentase respon siswa terhadap penerapan model CIRC $62 \%$ menyatakan sangat senang, 30,4\% senang dan 7,6\% kurang senang.Berdasarkan pengamatan peneliti, adanya perbedaan hasil belajar model Cooperative Integrated Reading and Composition (CIRC) menggunakan peta konsep dan peta pikiran disebabkan karena peta pikiran dan peta konsep memiliki kekurangan dan kelebihan masing-masing. Dalam peta konsep terdapat banyak konsep-konsep yang bersifat terstruktur, sehingga siswa memiliki kesempatan untuk menghubungkan pengetahuan dari satu konsep ke konsep lainnya untuk meningkatkan pemahaman siswa. Kelemahannya adalah pada saat membuat petakonsep diperlukan waktu yang lama, sedangkan peta pikiran dibuat dengan banyak menggunakan warna sehingga siswa dapat berkreasi membangun peta pikiran mereka sesuai materi yang ada. Penggunaan warna mampu menarik perhatian siswa untuk mempelajari materi di dalamnya. Tetapi, hal ini dapat membuat siswa cenderung berkreasi dengan warna yang ada dan dikhawatirkan tidak fokus terhadap substansi materi pelajaran.

Perbedaan pemberian perlakuan pada kedua kelas eksperimen membuat prestasi belajar mereka berbeda. Melalui peta konsep, diharapkan siswa mampu berperan aktif dalam memetakan konsep sehingga menjadi lebih efektif daripada pembelajaran konvensional yang pasif. Dalam membuat peta konsep, siswa menempuh sederetan proses yaitu membaca bahan pelajaran, menentukan konsep utama, konsep khusus, contohcontoh, kata penghubungnya ,dan menghubungkan konsep-konsep tersebut.

Kenyataan yang terjadi di lapangan, belum semua siswa mampu menemukan konsep yang ada pada materi. Mereka seperti kesulitan membuat peta konsep. Peta pikiran memberikan suasana baru bagi siswa kelas eksperimen II. Peta pikiran dikemas dengan permainan warna, sehingga dapat memberikan daya tarik tersendiri bagi siswa. Selain itu, peta pikiran juga praktis dalam membuat poin- 
poin materi sesuai dengan pemahaman siswa sehingga siswa bisa mengatasi kesulitan pada materi tersebut. Siswa akan sangat antusias saat membuat peta pikiran karena faktor warna yang digunakan memengaruhi ingatan siswa.

\section{KESIMPULAN}

Dari hasil penelitian dapat disimpulkan bahwa penggunaan model pembelajaran CIRC (Cooperative Integrated Reading and Composition) dilengkapi peta pikiran memberikan prestasi belajar yang lebih baik dibandingkan yang dilengkapi peta konsep pada materi pokok Sistem Koloid. Hal ini dibuktikan dengan hasil perhitungan menggunakan uji t-pihak kanan dengan taraf signifikan 5\%. Pada hasil uji t-pihak kanan untuk prestasi belajar kognitif diperoleh $t_{\text {hitung }}=2,2181>$ $\mathrm{t}_{\text {tabel }}=2,002$ dan untuk prestasi belajar afektif diperoleh $t_{\text {hitung }}=2,2181>t_{\text {tabel }}=$ 2,002 .

\section{Ucapan Terima Kasih}

Terima kasih kepada semua pihak yang membantu dalam penelitian ini, baik mahasiswa, guru, dan sekolah yang menjadi tempat dilaksanakannya peneltian.

\section{DAFTAR PUSTAKA}

Hanum, A., Hasan, M., \& Khaldun, I. (2014). Pembelajaran Model Cooperative Intergrated and Composition (CIRS) pada Materi Koloid di SMA Negeri 12 Banda Aceh. Jurnal Pendidikan Sains Indonesia, 2(1): 1-11.

Istarani. (2012). 58 Model Pembelajaran Inovatif. Medan : Media Persada.

Jati, Y. B., Mulyani, S., \& Hastuti, B. (2015). Pembelajaran Model Cooperative Integrated Reading and Composition (CIRC) Menggunakan Peta Konsep dan Peta Pikiran pada Materi Pokok Sistem Koloid Kelas XI Semester Genap SMA N 1 Sragen
Tahun Pelajaran 2012/2013. Jurnal Pendidikan Kimia (JPK), 4(1): 104112.

Margianto, N. (2017). Peningkatan Hasil Belajar Matematika Melalui Implementasi Metode Pembelajaran Coopertaive Learning Tipe Cooperative Integrated Reading and Composition (CIRC) pada Siswa SMA Negeri 1 Punggur. Jurnal Pendidikan Matematika FKIP Univ. Muhammadiyah Metro, 6(1): 107114.

Sukarini, A., Susilowati, E., \& Martini, K. S. (2013). Studi Komparasi Pembelajaran Kimia Menggunakan Metode Jigsaw dan Cooperative Integrated Reading and Composition (CIRC) Terhadap Prestasi Belajar Siswa pada Materi Koloid Kelas XI Semester 2 SMA Negeri 1 Wonogiri Tahun Ajaran 2011/2012. Jurnal Pendidikan Kimia (JPK), 2(3): 77-84. Wardani, E. K. \& Suharto, B. (2015). Meningkatkan Hasil Belajar Hidrokarbon dengan Model Cooperative Integrated Reading and Composition (CIRC) Berbantuan Media Buletin Siswa Kelas X-6 SMA Negeri 8 Banjarmasin. Jurnal Inovasi Pendidikan Sains, 6(2):66-77. 